\title{
足部内在筋は歩行中の足関節モーメントを変化させる機能を有する \\ Intrinsic foot muscles have the capacity to change ankle moment during gait
}

\author{
岡村 和典 ${ }^{1,2) *}$, 金井 秀作 ${ }^{3)}$, 沖井 明 ${ }^{1)}$, 江川 晃平 ${ }^{1)}$ \\ 山本 征孝 ${ }^{4}$, 沖 貞明 ${ }^{3)}$

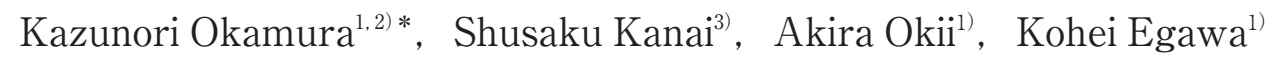 \\ Masataka Yamamoto ${ }^{4)}$, Sadaaki $\mathrm{Oki}^{3)}$ \\ 要旨：【目的】本研究の目的は, 足部内在筋が歩行中の足関節モーメントを变化させる機 \\ 能を有しているか検証することである。 \\ 【対象と方法】健常成人男性11名を対象とした。歩行立脚期に㧍ける足部内在筋の収縮力 \\ を電気刺激によって強化し，それに伴う足関節モーメントの変化を測定した。測定には三 \\ 次元動作解析装置と床反力計を使用した。 \\ 【結果】足部内在筋への電気刺激は, 歩行立脚期に拀ける最大内部足関節回内モーメント \\ を有意に増加させた $(\mathrm{p}<0.05)$ 。一方，底屈㧍よび外転モーメントに有意差は確認され \\ なかった。 \\ 【結語】本研究の結果からは, 回内作用を持つ足関節底屈筋の活動の増加だけでなく, 回 \\ 外作用を持つ足関節底屈筋の活動の低下も推察される。これは, 足部内在筋に歩行場面に \\ おける足部外在筋の活動を軽減させる機能が備わっていることを示唆している。 \\ キーワード : Intrinsic foot muscles, Extrinsic foot muscles, Interaction, Electrical stimula- \\ tion, Ankle moment, Gait. \\ Abstract: 【Objective】 The purpose of this study was to examine whether the intrinsic \\ foot muscles have the capacity to change ankle moment during gait. \\ 【Methods】 Eleven healthy male subjects participated in this study. The change in ankle \\ moment during stance phase that results from the reinforcement of the intrinsic foot mus- \\ cles stimulated by electrical stimulation was analyzed. \\ 【Result】 Following the electrical stimulation of the intrinsic foot muscles during stance \\ phase, the maximum internal ankle eversion moment significantly increased $(p<0.05)$. \\ However, the maximum values of other internal ankle moments (plantar flexion and ab- \\ duction) did not change. \\ 【Conclusion】 The results of this study indicated that not only the increased activity of the \\ ankle eversion muscles was caused by the reinforcement of the intrinsic foot muscles, but \\ also the decreased activity of the ankle inversion muscles was caused as well. This may \\ suggest that the intrinsic foot muscles have the capacity to decrease activity of the extrin- \\ sic foot invertor muscles during gait.
}

Key words: Intrinsic foot muscles, Extrinsic foot muscles, Interaction, Electrical stimulation, Ankle moment, Gait.

\footnotetext{
受付日：2016年10月31日，採択日：2016年11月22日

1) 医療法人和会沖井クリニック

Okii Clinic：=740-0012 山口県岩国市元町 4丁目 5-10 Tel：0827-21-0720 Fax：0827-21-0723

E-mail : okamura_kazunori0622@yahoo.co.jp

2) 県立広島大学大学院総合学術研究科

Graduate School of Comprehensive Scientific Research, Prefectural University of Hiroshima

3) 県立広島大学保健福祉学部理学療法学科

Department of Physical Therapy, Faculty of Health and Welfare, Prefectural University of Hiroshima

4) 兵庫県立淡路医療センターリハビリテーション科

Department of Rehabilitation, Hyogo Prefectural Awaji Medical Center
} 


\section{I 、はじめに}

ヒトの足部は特徵的なアーチ構造を呈している。こ のアーチ構造は，骨や勒帯等の静的支持機構だけでな く足部の内在筋 ${ }^{1,2)}$ や外在筋 ${ }^{3,4)}$ といった動的支持機構 によっても支持されており，近年これらの筋の相互関 係を示唆する報告が散見されるようになってきた。 Angin $ら^{5)}$ は足部の内側縦アーチ（Medial longitudinal arch：以下，MLA）を支持している筋の横断面積を 調べ, 扁平足症例は正常な足部アライメントを呈する 者に比へ，足部内在筋である母趾外転筋や短母趾屈筋 の筋横断面積が減少しており, 一方で長母趾屈筋や長 趾屈筋といった足部外在筋の筋横断面積は増加してい ることを発見した。さらに扁平足症例の歩行立脚期に おいて, 後脛骨筋の筋活動の増加 ${ }^{6)}$ や足関節内部底屈 および回外モーメントの増加 ${ }^{7)}$ 報告されている(本 研究では足関節の前額面上での運動を回内・外, 三平 面上での複合運動を内・外返しと定義)。これらの報 告から扁平足症例では荷重動作中, 足部内在筋や静的 支持機構の MLA 支持機能の低下に対し, 長母趾屈筋 や後脛骨筋などの足関節内返し作用を持つ足部外在筋

(Extrinsic foot invertor muscle：以下, EFI) が代償 的に筋活動を増加させていることが示唆されている。

一方これらの知見を逆説的にとらえると, 足部内在筋 の強化によって荷重動作中の EFIの負担を軽減させ ることができる可能性もある。脛骨過労性骨膜炎は MLAの低下がリスク因子に含まれる代表的な下肢の 過用性障害8 ${ }^{89}$ であるが, その発症には EFIによる脛 骨骨膜への星引ストレスが関与すると考えられてお $り^{9)}$, 扁平足症例にみられる $\mathrm{EFI} の$ 代償的な過活動は $\mathrm{EFI}$ の伸張性の低下とともにこの牽引ストレスを増加 させる要因となり得る。したがって, 足部内在筋の強 化が荷重動作中の EFIの負担を軽減させるという可 能性は, 脛骨過労性骨膜炎に対する足部内在筋卜レー ニングの新しい視点となる。しかし，これまでのとこ ろ荷重動作中の EFIの負担軽減という視点から足部 内在筋の機能を検証した報告は見当たらない。

足部内在筋が動的場面における EFIの負担を軽減 させる機能を有しているかどうかは, 足部内在筋の筋 力強化をシュミレーションすることで検証が可能であ る。Kelly $ら^{2)}$ は足部内在筋の MLA 支持機能を検証す るために, 電気刺激を用いて足部内在筋の筋力強化を 再現している。足部内在筋の筋力強化の再現に電気刺 激を用いた場合, EFIの活動を筋電図学的に検証する ことが困難となるが, そもそも EFI は下腿の深層に
位置しているため筋電図では非侵襲的な評価が不可能 である。筋電困以外で動的場面における筋の活動の程 度を評価する手段としては，関節モーメントの算出が 挙げられる。この方法は個別の筋の活動を評価できな いことや拮抗筋の影響を取り除けないといった限界が あるものの, 電気刺激によって再現された足部内在筋 の筋力強化に伴う EFIの活動の変化を, 動的場面に おいて非侵襲的に評価する手段としては適している。

そこで本研究では，動的場面における EFIの負担 軽減という視点から足部内在筋の機能を検証する目的 で，電気刺激によって再現した足部内在筋の筋力強化 が歩行中の足関節モーメントに及ぼす影響を明らかに する。

\section{II. 方 法 \\ 1. 対 象}

対象は健常成人男性 11 名 $(21.0 \pm 1.3$ 歳, $171.8 \pm 6.3$ $\mathrm{cm}, 62.6 \pm 7.0 \mathrm{~kg})$ ，被験肢は右下肢とした。実験前 6 力月以内に下肢に整形外科的な既往のある者および 過度な後足部回内アライメントを呈する者は対象から 除外した。後足部回内アライメントの評価には navicular drop を用い, 先行研究 ${ }^{10,11)}$ に従って navicular drop が $10 \mathrm{~mm}$ を超えることを過度な後足部回内アライメン 卜と定義した。なお，本研究は県立広島大学倫理委員 会の承認を受けており（承認番号：第16MH0245号）, 対象には事前に口頭および書面にて本研究について十 分な説明を行い，同意を得た上で実験を開始した。

\section{2. 使用機器}

本研究では，機能的電気刺激装置ウォークエイド $\mathrm{R}$ （帝人ファーマ株式会社：図 1）を用いて足部内在筋 への電気刺激を行った。これは本来，脳卒中片麻瘏患 者の歩行遊脚期に足関節背屈筋群を電気刺激すること でその機能再建をはかるための機器であるが，ハンド スイッチによって自由に刺激のタイミングを調節でき ることから，本研究では歩行立脚期における足部内在 筋への電気刺激に応用した。歩行中の足関節モーメン トの測定には三次元動作解析装置 VICON（Oxford Metrics, UK：赤外線カメラ MX-T20S12台, 100Hz) と床反力計 6 台 (Kistler 2 台, AMTI 4 台, $1000 \mathrm{~Hz}$ ) を用い，測定データはVICON NEXUS 2ソフトウェ アを用いて処理した。 


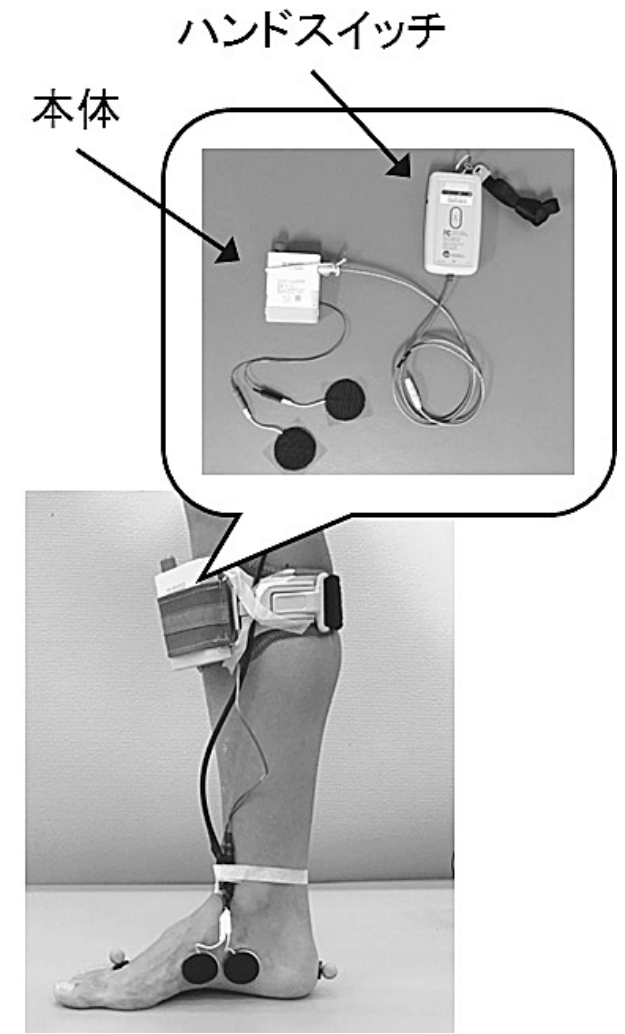

図 1 機能的電気刺激装置ウォークエイドRと電極貼付位置

\section{3 . 足部内在筋への電気刺激}

電気刺激（周波数 $20 \mathrm{~Hz}$ ，パルス幅 $250 \mu \mathrm{sec}$ ）は母趾 外転筋を主とした足部内在筋に対し，母趾外転筋の筋 腹に貼付した表面電極を介して与えられた（図 1)。 正常歩行においてこれらの筋が活動するとされる立脚 中期〜前遊脚期までの区間 ${ }^{12)}$ を検者が視覚的に判断し， ハンドスイッチを押すことで対象の足部内在筋に電気 刺激を与えた。またウォークエイドRをVICONに同 期 $(1000 \mathrm{~Hz})$ することによって, 電気刺激のタイミ ングの確認を可能にした。電気刺激の強度は痛みを感 じない最大の刺激強度と定義した。

\section{4.データ収集}

測定に先立って，対象の身長，体重，骨盤幅，両側 の棘果長，膝関節幅，足関節幅の測定を実施した。そ の後, Plug-in Gait下肢モデルの16点に右側舟状骨結 節への追加マーカーを加えた計 17 点に反射マーカー

（14mm）を貼付し，続いて右側の下腿に電気刺激装 置を，母趾外転筋の筋腹に表面電極をそれぞれ装着し た。以上の準備が整った後, 静止立位の測定をキャリ ブレーションとして1回実施した。続いて, 対象は電 気刺激の無い条件下で $8 \mathrm{~m}$ 歩行路を快適歩行速度にて 歩行するよう指示された。床反力計に自然かつ確実に
接地できるまで十分な練習が繰り返された後，5回の 成功試行が得られるまで対象の歩行を測定した。その 後, 各対象における痛みを感じない最大の電気刺激強 度を決定し，足部内在筋への電気刺激を加えた条件下 での歩行の測定へと移行した。電気刺激を加えた条件 下での歩行の測定も5 回の成功試行が得られるまで実 施した。電気刺激の有無を問わず，全ての試行は電気 刺激装置を操作する検者が対象に並走する環境下で実 施した（図 2 )。また電気刺激によって誘発された足 部内在筋の収縮力を先行研究と比較する目的で, 右下 肢に体重の $90 \%$ を荷重した立位 ${ }^{13} に に お け る$ 床から舟状

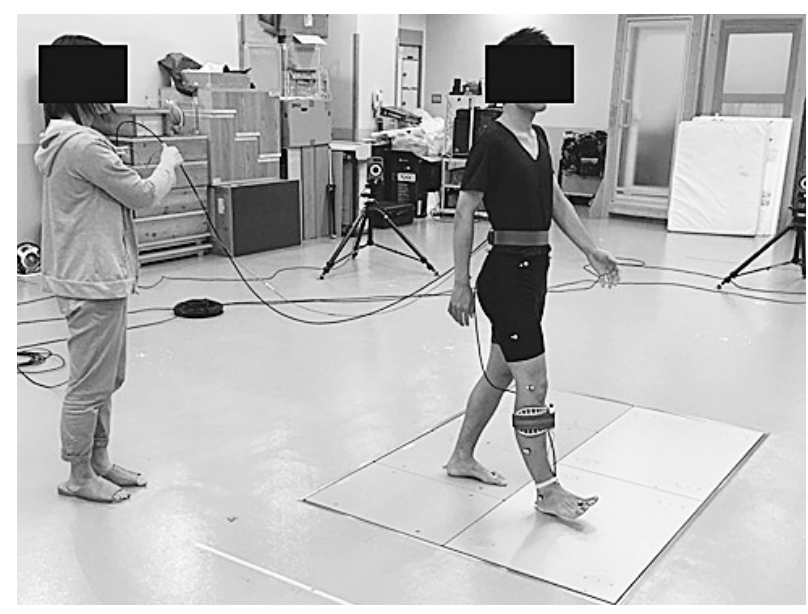

図 2 実験風景

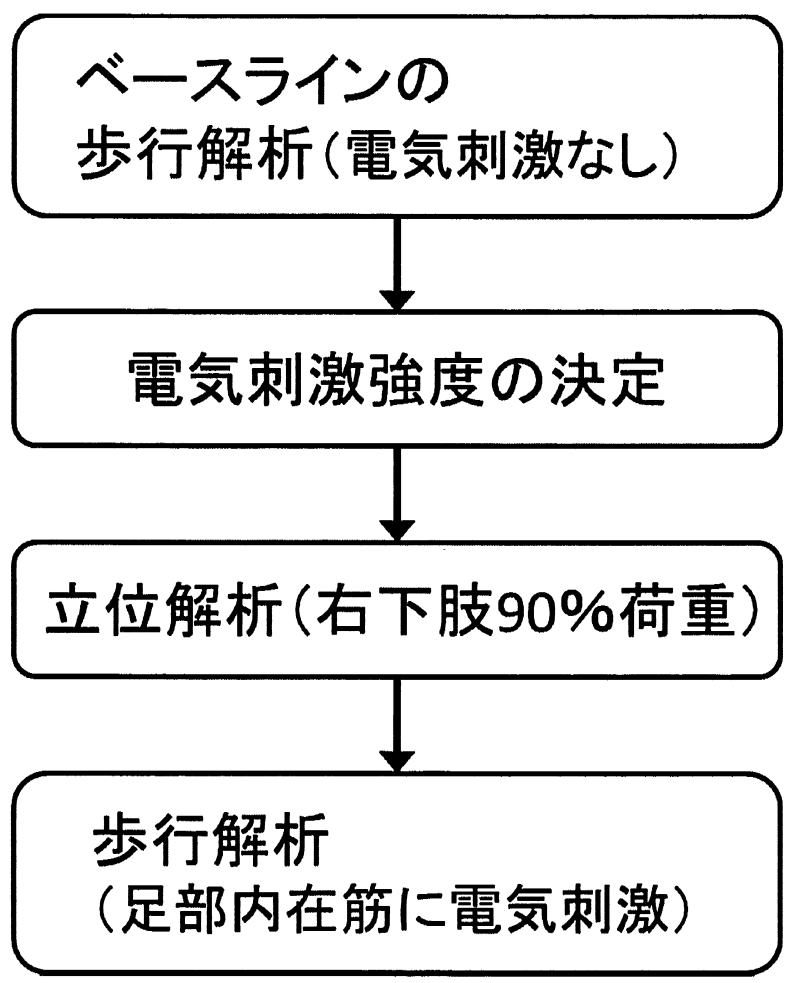

図 3 実験プロトコール 
骨マーカーまでの高さ (以下, 舟状骨高)を10秒間 (後 半 5 秒間のみ電気刺激を実施）測定した。この測定は 電気刺激強度の決定直後に 1 回のみ実施した（図 3 )。

\section{5. 統計学的分析}

対象の各条件における歩行速度, 右側立脚時間, 右 側立脚期における最大内部足関節モーメント（底屈, 回内, 外転) を算出し, 各解析項目ごとに 5 回の試行 の中で最大值, 最小值を省いた 3 試行分の值を平均し たものを代表值とした。これらの項目に対し ShapiroWilk 検定を行い, 正規性が確認されなかった歩行速 度と右側立脚時間については Wilcoxon の符号付順位 検定を，その他の項目については対応のある $\mathrm{t}$ 検定を 用いて足部内在筋への電機刺激に伴う変化を比較した。 また，右下肢に体重の $90 \%$ を荷重した立位に扮ける舟 状骨高についても，正規性を確認した上で電気刺激の 有無による変化を対応のある $\mathrm{t}$ 検定を用いて比較した。 立位における舟状骨高は，10秒間の測定の後半 5 秒間 のみ電気刺激を伴うデータであることから，前後半 5 秒間のうちそれぞれ中央 3 秒間の平均值を統計学的に 比較した。全ての統計学的分析にはSPSS 20.0 for Windows を使用し，有意水準は $\mathrm{p}<0.05$ とした。

\section{III. 結 果}

対象の歩行速度および右側立脚時間について, 電気 刺激の有無による統計学的な有意差は確認されなかっ た (表 1 )。また, 足部内在筋への電気刺激は歩行周 期の $19.2 \pm 2.6 \%$ から $55.1 \pm 2.9 \%$ までの間に実施さ れていた。

図 4 に歩行立脚期に扮ける足関節角度と内部足関節
モーメントの変化を示す。母趾外転筋を中心とした足 部内在筋への電気刺激は, 歩行立脚期における最大内 部足関節回内モーメントを有意に増加させた（114.3 $\pm 73.3[\mathrm{~N} \cdot \mathrm{mm} / \mathrm{kg}] \rightarrow 154.3 \pm 74.7[\mathrm{~N} \cdot \mathrm{mm} / \mathrm{kg}], \mathrm{p}=$ 0.039)。一方, 底屈および外転モーメントに有意差は 確認されなかった（表 2 )。また，立位に打ける舟状 骨高は電気刺激によって有意に増加した（49.6 6 6.4 $[\mathrm{mm}] \rightarrow 51.1 \pm 6.2[\mathrm{~mm}], \mathrm{p}=0.027 ） （$ 表 2 )。

\section{IV. 考 察}

本研究では, 足部内在筋の収縮力の強化が歩行立脚 期の足関節モーメントに及ぼす影響を確認することで, 歩行場面に打ける EFIの負担軽減という視点から足 部内在筋の機能の検証を試みた。

本研究で用いた「痛みを感じない最大の電気刺激強 度」は，右下肢に体重の $90 \%$ を荷重した立位に㧍ける 舟状骨高を平均 $1.5 \mathrm{~mm}$ 増加させる程度の足部内在筋 の収縮力の強化を再現した。Mulligan ら ${ }^{13)}$ は，4 週間 の足部内在筋トレーニングによって同肢位での舟状骨 高が平均 $1.8 \mathrm{~mm}$ 増加したことを報告している。この 変化は本研究と同程度であることから, 本研究に㧤い て再現された足部内在筋の収縮力の強化は非生理的に 強いものではなかったと考えられる。また, 本研究に おける足部内在筋への電気刺激は歩行周期の $19.2 \pm$

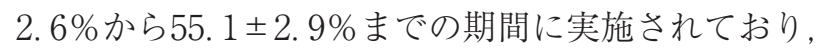

これは立脚中期の中盤から前遊脚期に相当する。本研 究で電気刺激の影響をより強く受けたことが予測され る母趾外転筋と短母趾屈筋は，それぞれ歩行周期の 40\%，20\%から活動を開始することが報告されてい る ${ }^{12)}$ 。本研究では表面電極を用いたため, それぞれの

表 1 足部内在筋への電気刺激に伴う歩行速度と立脚時間の変化

\begin{tabular}{l|cccc}
\hline & $\begin{array}{c}\text { ベースライン } \\
\text { Median (Q25/Q45) }\end{array}$ & $\begin{array}{c}\text { 電気刺激 } \\
\text { Median (Q25/Q45) }\end{array}$ & $\mathrm{P}$ \\
\hline 歩行速度 $(\mathrm{m} / \mathrm{s})$ & $1.3(1.1 / 1.4)$ & $1.2(1.2 / 1.4)$ & 1.00 \\
右側立脚時間 $(\mathrm{s})$ & $0.7(0.6 / 0.7)$ & $0.6(0.6 / 0.7)$ & 0.56 \\
\hline \multicolumn{4}{r}{$\mathrm{*}<0.05$}
\end{tabular}

表 2 足部内在筋への電気刺激に伴う内部足関節モーメント（歩行）と舟状骨高（立位）の変化

\begin{tabular}{rl|ccrrr}
\hline & & $\begin{array}{c}\text { ベースライン } \\
\text { Mean } \pm \text { SD }\end{array}$ & $\begin{array}{c}\text { 電気刺激 } \\
\text { Mean } \pm S D\end{array}$ & Mean Diff & 95\%CI & P \\
\hline 足関節モーメント & 底屈 & $1383.1 \pm 170.8$ & $1341.8 \pm 143.6$ & 41.3 & -35.9 to 118.5 & 0.26 \\
$(\mathrm{~N} \cdot \mathrm{mm} / \mathrm{kg})$ & 回内 & $114.3 \pm 73.3$ & $154.3 \pm 74.7$ & -40.0 & -77.6 to -2.3 & $0.04^{*}$ \\
& 外転 & $115.1 \pm 33.0$ & $153.3 \pm 88.6$ & -38.2 & -94.8 to 18.5 & 0.16 \\
\hline 舟状骨高 $(\mathrm{mm})$ & & $49.6 \pm 6.4$ & $51.1 \pm 6.3$ & -1.5 & -2.7 to -0.2 & $0.03^{*}$ \\
\hline
\end{tabular}



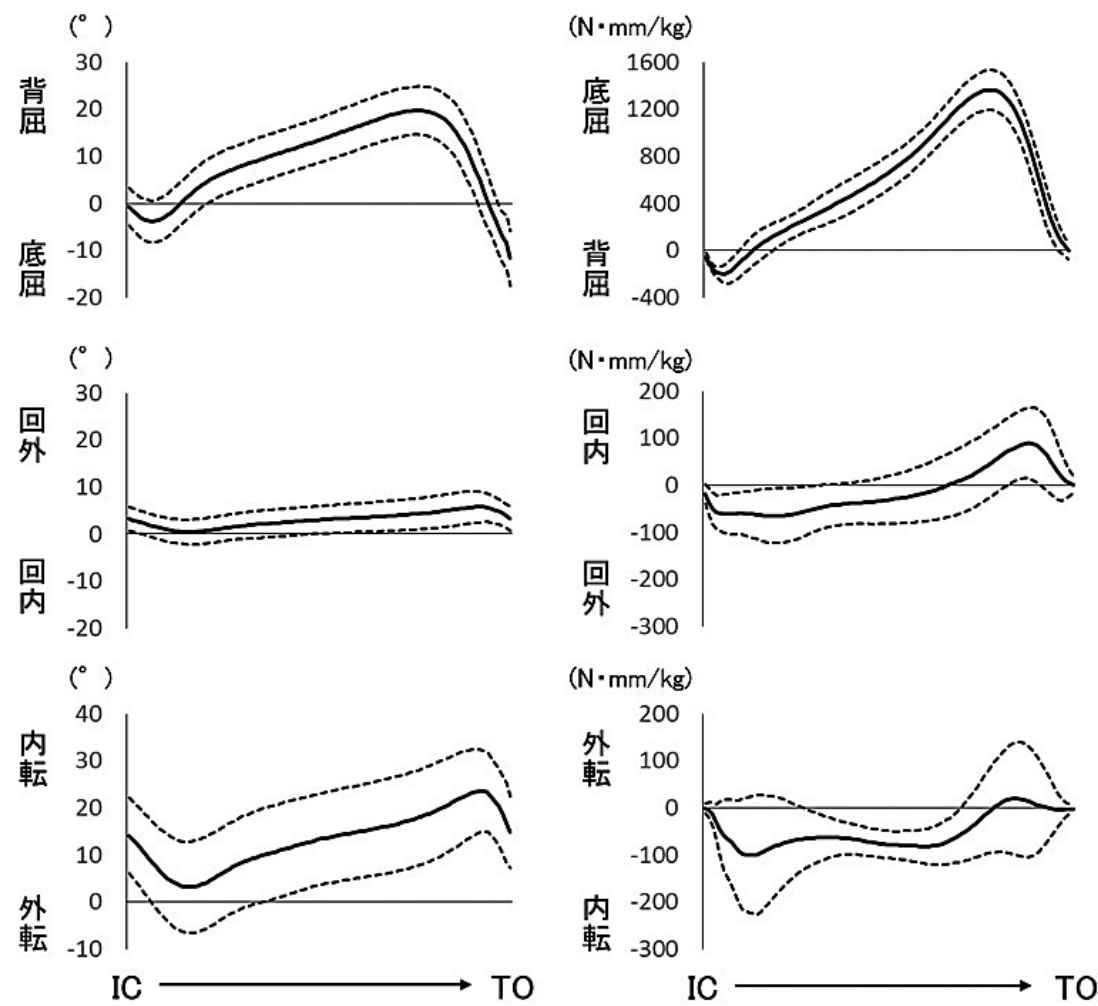

図 4 歩行立脚期の足関節角度と内部足関節モーメントの変化 実線：平均值, 破線：標準偏差, IC : initial contact, TO : toe off

筋に最適なタイミングで電気刺激を与えることは困難 であったが，本研究の電気刺激はいずれの筋の活動開 始時間にも遅れることなく与えられていた。

興味深いことに本研究では, 足部内在筋の収縮力の 強化は歩行立脚期における最大内部足関節底屈モーメ ントを変化させることなく回内モーメントにのみ有意 な増加を引き起こした。正常歩行において足関節底屈 筋群はいずれも立脚終期に最大の筋活動を示し ${ }^{12)}$ ，こ れは内部足関節底屈モーメントと回内モーメントが最 大值に達する時期でもある。足関節底屈筋群はその走 行によってヒラメ筋や後脛骨筋，長母趾屈筋など足関 節の回外に関与する筋と長腓骨筋のように回内に関与 する筋に分けられることから，立脚終期の最大内部足 関節回内モーメントとは，個々の足関節底屈筋の活動 に伴う足関節回内方向へのモーメントの総和から回外 方向へのモーメントの総和を引いたものであると解釈 できる。そのため, 最大内部足関節底屈モーメントが 変化せず回内モーメントのみ増加したという本研究の 結果からは, 回内作用を持つ足関節底屈筋の活動の増 加だけでなく，回外作用を持つ足関節底屈筋の活動の 低下も推察され，足部内在筋には歩行場面に打ける EFIの活動を軽減させる機能が備わっている可能性が あると考えられる。本研究の結果は, 荷重動作中の EFI
の活動を抑制する手段としての足部内在筋トレーニン グの有用性を提案するものであり，冒頭で述べた脛骨 過労性骨膜炎 ${ }^{8.9}$ の予防や治療に役立つ知見であると考 える。

本研究の限界として，まず足関節モーメントを通し てEFIの活動を推測している点が挙げられる。冒頭 で述べたように，関節モーメントからは個別の筋の活 動を評価することができないため，EFIの活動の低下 を直接証明することはできない。しかし，今後侵襲を 伴う筋電図学的な検証を進めていくための基礎デー夕 として, 本研究の結果は意義のあるものだと考えてい る。

次に, 足部内在筋への電気刺激に伴う痛み等の感覚 入力が結果に影響を及ぼした可能性がある。しかし， 本研究では足部の内側に貼付した電極から電気刺激を 行ったため, 痛み等の感覚入力に対する逃避が生じた とすれば内部足関節回内モーメントは低下するはずで あることから，この可能性は低いと考えている。

また，本研究では電気刺激の持ち越し効果に対する 危惧から，いずれの測定も「電気刺激なし」 $\rightarrow$ 「電気 刺激あり」の順序で行った。しかし，測定回数等の電 気刺激以外の影響を取り除くためには，コントロール 群を設けた研究デザインがより望ましい。 
最後に, 本研究では EFIの負担軽減という視点か らの足部内在筋の機能を, 歩行場面において検証した に過ぎない。先行研究 ${ }^{14)}$ において母趾外転筋の筋活動 が歩行よりも走行時に有意に増加すると報告されてい ることや，MLAの低下が関係する過用性障害の多く がより負荷の大きい活動を行う対象に発症することを 考慮すると，今後は走行場面における検証も必要であ る。

\section{文献}

1) Wong YS.: Influence of the abductor hallucis muscle on the medial arch of the foot: a kinematic and anatomical cadaver study. Foot Ankle Int, 2007, 28(5): 617-620.

2) Kelly LA, Cresswell AG, Racinais S, et al.: Intrinsic foot muscles have the capacity to control deformation of the longitudinal arch. J R Soc Interface, 2014, 11(93): 20131188.

3) Imhauser $\mathrm{CW}$, Siegler S, Abidi NA, et al.: The effect of posterior tibialis tendon dysfunction on the plantar pressure characteristics and the kinematics of the arch and the hindfoot. Clin Biomech, 2004, 19(2): 161-169.

4) Kokubo T, Hashimoto T, Nagura T, et al.: Effect of the posterior tibial and peroneal longus on the mechanical properties of the foot arch. Foot Ankle Int, 2012, 33(4): 320-325.

5) Angin S, Crofts G, Mickle KJ, et al.: Ultrasound evaluation of foot muscles and plantar fascia in pes planus. Gait Posture, 2014, 40(1): 48-52.

6) Murley GS, Menz HB, Landorf KB.: Foot posture influences the electromyographic activity of selected lower limb muscles during gait. J Foot Ankle Res, 2009, 2: 35.

7) Hunt AE, Smith RM.: Mechanics and control of the flat versus normal foot during the stance phase of walking. Clin Biomech, 2004, 19(4): 391-397.

8) Newman P, Witchalls J, Waddington G, et al.: Risk factors associated with medial tibial stress syndrome in runners: a systematic review and meta-analysis. Open Access J Sports Med, 2013, 13(4): 229-241.

9) Reshef N, Guelich DR.: Medial tibial stress syndrome. Clin Sports Med, 2012, 31(2): 273-290.

10) Mueller MJ, Host JV, Norton BJ.: Navicular drop as a composite measure of excessive pronation. J Am Podiatr Med Assoc, 1993, 83(4): 198-202.

11) O'Sullivan K, Kennedy N, O'Neill E, et al.: The effect of lowdye taping on rearfoot motion and plantar pressure during the stance phase of gait. BMC Musculoskelet Disord, 2008, 18(9): 111.

12) Jacquelin Perry, Judith M. Burnfield, 武田功（訳） ·他： ペリー歩行分析：正常歩行と異常歩行第 2 版. 医歯薬出版, 東京, 2012，46-47.

13) Mulligan EP, Cook PG.: Effect of plantar intrinsic muscle training on medial longitudinal arch morphology and dynamic function. Man Ther, 2013, 18(5): 425-430.

14) Kelly LA, Lichtwark G, Cresswell AG.: Active regulation of longitudinal arch compression and recoil during walking and running. J R Soc Interface, 2015, 12(102): 20141076. 